\title{
Pulmonary function and exercise capacity in metal industry workers
}

\author{
Mônica V. Gonçalves ${ }^{\mathrm{a}^{*}}$, Rosane F. Bernardes ${ }^{\mathrm{a}}$, Luciana D. Chiavegato ${ }^{\mathrm{a}}$, Rosimeire S. Padula ${ }^{\mathrm{a}}$ \\ ${ }^{a}$ Universidade Cidade de São Paulo, R. Cesário Galeno, 448, São Paulo, Brazil
}

\begin{abstract}
This article intends to evaluate the lung function and capacity to exercise and correlate both of them in metal industry workers.
\end{abstract}

Keywords: Occupacional health, Health condictions, Pulmonary function, Exercise capacity.

\section{Introduction}

Brazil doesn't have a strong and specific health worker program and culture for this. Fortunately, the worries ${ }^{[1]}$ The companies started to take care of the workers health and this kind of program became necessary and prosperous. The years worked can be associate to health problems such as pulmonary function and exercise capacity decrease ${ }^{[2]}$ Pulmonary function and six minute walking tests are important tools to evaluate respiratory diseases coming from enviroment and work influences and they are very important also to check the diseases evolution ${ }^{[3-4]}$ Objectives: Evaluate the pulmonary function and exercise capacity in industrial workers.

\section{Methods}

Crossection study in metal industry workers, both sex, 20 to 70 years old, whose are exposure to high temperatures activities. They were submit to respiratory evaluation:forced vital capacity (FVC), expiratory volume in the first second $\left(\mathrm{VEF}_{1}\right)$ and expiratory peak flow and six minute walking test. After evaluation they answered a questionnaire about physical activities and self health perception.

\section{Results}

It was evaluate 68 workers, $34 \pm 8$ years old, $\mathrm{FVC}=$ $456 \pm 1$, 05 litros, $\mathrm{FEV}_{1}=3,77 \pm 0,81$ litros e $\mathrm{PFE}=497 \pm 135$ ltros $($ Table 1$)$.

They walked $644 \pm 85$ meters (Table2).

Table 1

Characteristics of 68 metal industry workers

\begin{tabular}{cc}
\hline Variable & Mean (SD) \\
\hline Age(years) & $34.23(8.35)$ \\
Work age(years) & $6.49(6.75)$ \\
Weight $(\mathrm{kg})$ & $73.47(9.56)$ \\
Height $(\mathrm{cm})$ & $169(7)$ \\
\hline
\end{tabular}

Table 2

Six minute walk test

\begin{tabular}{ccc}
\hline Variable & Mean & $\begin{array}{c}\text { Standard } \\
\text { Deviation }\end{array}$ \\
\hline Distance $(\mathrm{m})$ & 644.36 & 85.95 \\
$\mathrm{SpO}_{2}(\%)$ & 94.46 & 4.72 \\
$\mathrm{HR}(\mathrm{bpm})$ & 101.19 & 24.91 \\
Borg scale & 2.98 & 2.36 \\
$\begin{array}{c}\mathrm{BP} \text { before } \\
(\mathrm{mmHg})\end{array}$ & 97.31 & 11.05 \\
$\begin{array}{c}\mathrm{BPafter} \\
(\mathrm{mmHg})\end{array}$ & 101.98 & 9.53
\end{tabular}

Six minute walk test: mean and standard deviation of distance, Pulse oximetry $\left(\mathrm{SpO}_{2}\right)$, Borg scale, heart rate(HR) and Blood pressure (BP) of 68 metal industry workers

${ }^{*}$ Corresponding author. E-mail: rosipadula@gmail.com 


\section{Discussion}

The results show us that exposure to high temperatures and heavy metals didn't promote important changes in pulmonary function and exercise capacity in this population. Besides that, suggest the necessity to keep workers well evaluate and well informed about care protection for their activities and usual care about their health.

\section{References}

[1] Kenny GP, Yardley JE, Martineau L, Jay O. Physical work capacity in older adults : implications for the aging worker. . Am J Ind Med. 2008;51(8):610-15.

[2] Soares CPS, al e. Avaliação da aplicabilidade da equação de referência para estimativa de performance no Teste de Caminhada de 6 minutos. . Revista da Sociedade de Cardiologia 2004;14(2):supl A.

[3] Solway S, Brooks D, Lacasse Y, Thomas S. A qualitative systematic overview of the measurement properties of functional walk tests used in the Cardiorespiratory Domain Chest. 2001;119(1):256-70.

[4] Rodrigues SL, Mendes HF, A.Viegas CA. Teste de caminhada de seis minutos: estudo do efeito do aprendizado em portadores de doença pulmonar obstrutiva crônica. Jornal Brasileiro de Pneumologia. 2004, 30(2):121-5. 